\title{
Arbeidsongevallen met lichamelijk en geestelijk letsel en de relatie met ziekteverzuim
}

\author{
Jan Fekke Ybema en Karin Jettinghoff
}

In dit artikel staat centraal in hoeverre arbeidsongevallen met lichamelijk en geestelijk letsel samengaan met verzuim van werknemers. Hiervoor zijn analyses uitgevoerd op een groot databestand met gegevens van 10.075 Nederlandse werknemers. Dit bestand is representatief voor alle werknemers in Nederland wat betreft geslacht, leeftijd en bedrijfssector. Uit het onderzoek blijkt dat werknemers die in de afgelopen twaalf maanden een arbeidsongeval hebben meegemaakt dat leidde tot geestelijk letsel, in dat jaar langduriger verzuimden dan werknemers die geen arbeidsongeval hadden meegemaakt of een arbeidsongeval meemaakten dat leidde tot lichamelijk letsel. Verder lijken werknemers met geestelijk letsel door een arbeidsongeval hun verzuim als gevolg van dat ongeval lager in te schatten dan gerechtvaardigd is. Werknemers met lichamelijk letsel door een arbeidsongeval schatten hun verzuim wel goed in.

Trefwoorden: arbeidsongevallen, ziekteverzuim, lichamelijk letsel, geestelijk letsel, zelfrapportage

\section{Inleiding}

Een arbeidsongeval, zoals de val van een steiger, een aanrijding met een heftruck of bekneld raken in een machine, kan ernstige gevolgen hebben voor de betrokken personen en voor het bedrijf waar zij werken. Een arbeidsongeval kan dodelijk zijn of kan leiden tot ernstige of minder ernstige lichamelijke verwondingen. Ook kan er geestelijk letsel optreden, bijvoorbeeld angstgevoelens, onzekerheid of posttraumatische stress. Het lichamelijk of geestelijk letsel als gevolg van een arbeidsongeval kan ertoe leiden dat mensen tijdelijk of voorgoed hun beroep niet meer kunnen uitoefenen. Ook voor een bedrijf kunnen arbeidsongevallen aanzienlijke gevolgen hebben. Deze gevolgen hebben onder meer betrekking op kosten van ziekteverzuim en arbeidsongeschiktheid van de betrokken personen, materiële kosten (zoals beschadigde voertuigen, installaties of gebouwen), productieverlies, juridische kosten en immateriële schade (bijvoorbeeld imagoschade bij klanten of motivatieverlies bij het personeel).

In Nederland bedragen de kosten van het (werkgebonden) ziekteverzuim dat is toe te schrijven aan arbeidsongevallen naar schatting 135 miljoen euro op jaarbasis. Kosten van de WAO-instroom als gevolg van arbeidsongevallen bedragen ongeveer 55 miljoen euro per jaar (Mossink, Koningsveld \& Zwinkels, 2003). Voor een werkgever kunnen de kosten van een afzonderlijk arbeidsongeval naar schatting oplopen tot 430.000 euro, afhankelijk van de duur van verzuim, WAO-intrede, stilleggen van werk, schadeclaim van werknemer, boete van de Arbeidsinspectie en proceskosten (Venema \& Bloemhoff, 2004).

In dit artikel willen we nagaan hoe lichame-

\footnotetext{
* Beide auteurs zijn werkzaam bij TNO Kwaliteit van Leven I Arbeid. Correspondentieadres: dr. J.F. Ybema, TNO Kwaliteit van Leven I Arbeid, Postbus 718, 2130 AS Hoofddorp. E-mail: jan_fekke.ybema@tno.nl.

Deze publicatie is tot stand gekomen in het kader van het Doelfinancieringsprogramma 'Monitoring van Arbeid' dat TNO uitvoert in samenwerking met het ministerie van Sociale Zaken en Werkgelegenheid.
} 
Arbeidsongevallen met lichamelijk en geestelijk letsel en de relatie met ziekteverzuim

lijk en geestelijk letsel bij arbeidsongevallen samenhangt met het ziekteverzuim van de persoon. Daarbij kijken we enerzijds naar het verzuim dat de werknemer zelf toeschrijft aan het arbeidsongeval en anderzijds naar het verschil in het totale gerapporteerde verzuim van werknemers met en zonder een arbeidsongeval (vgl. De Vroome, Smulders \& Van Vuuren, 2005). Volgens de standaarddefinitie voor arbeidsongevallen - zoals gehanteerd in de Monitor Arbeidsongevallen - is er sprake van een arbeidsongeval als een voorval tijdens het werk leidt tot lichamelijke of geestelijke schade en tot ziekteverzuim van ten minste één dag (Venema \& Bloemhoff, 2004). Omdat dit onderzoek ingaat op de relatie van arbeidsongevallen met ziekteverzuim, nemen we hier ook arbeidsongevallen mee die niet leiden tot ziekteverzuim.

\section{Letsel als gevolg van arbeidsongevallen}

Over arbeidsongevallen met lichamelijk letsel is al het een en ander bekend. Uit de Enquête Beroepsbevolking (EBB) van het Centraal Bureau voor de Statistiek (CBS) blijkt dat in Nederland per jaar 2 procent van alle mensen die minimaal vier uur per week werken (circa 150.000 personen) betrokken is bij een of meer arbeidsongevallen resulterend in lichamelijk letsel, zoals een open wond of snijwond $(29,8 \%)$, kneuzing $(23,6 \%)$, verrekking of verstuiking $(14,8 \%)$, of botbreuk $(11,5 \%)$ (Beckers \& Smits, 2003).

Over geestelijk letsel als gevolg van arbeidsongevallen is nog maar weinig bekend. In onderzoek van Keogh et al. (2000) onder slachtoffers van een arbeidsongeval met letsel aan de bovenste extremiteiten werden bij 31 procent van deze slachtoffers depressieve symptomen gevonden. De Ridder (1993) stelde dat ernstige ongevallen op het werk bij zowel slachtoffers als andere betrokkenen kunnen leiden tot een posttraumatische stressstoornis (PTSS). Dit is bevestigd in onderzoek van Asmundson et al. (1998) waaruit bleek dat een aanzienlijk deel van werknemers betrokken bij een arbeidsongeval symptomen rapporteert die kenmerkend zijn voor een PTSS. Verder zijn er aanwijzingen dat arbeidsongevallen (ongeacht de ernst ervan) gepaard gaan met veranderingen in attitude ten aanzien van het werk, zoals toegenomen wantrouwen ten aanzien van het management, ervaren gebrek aan invloed, ontevredenheid met het werk en een hoger verloop (Barling, Kelloway \& Iverson, 2003).

\section{Verzuim als gevolg van arbeidsongevallen met letsel}

Over verzuim als gevolg van een arbeidsongeval is bekend dat ongeveer een derde van de personen die een arbeidsongeval hebben meegemaakt dat resulteerde in fysiek letsel, meteen weer aan het werk gaat na het ongeval. Van de personen die thuis zijn gebleven na het ongeval, geeft ongeveer een kwart aan langer dan één maand thuis te zijn gebleven (Beckers \& Smits, 2003). Over verzuim als gevolg van arbeidsongevallen met geestelijk letsel is nog weinig bekend. Wel is er iets bekend over de rol van psychische belasting in het werk bij ziekteverzuim na een arbeidsongeval. Boedeker (2001) vond in zijn onderzoek bij enkele grote bedrijven in de metaalverwerkende industrie en detailhandel, dat werknemers die betrokken zijn geweest bij een arbeidsongeval zich minder vaak ziek melden wanneer zij in hun werk te maken hebben met hoge psychische belasting. Voor hoge lichamelijke belasting en weinig controle in het werk gold het omgekeerde: betrokkenen bij een arbeidsongeval melden zich vaker ziek wanneer zij in hun werk te maken hebben met hoge lichamelijke belasting en weinig controlemogelijkheden. Volgens Boedeker is het lagere verzuim onder medewerkers met een hoge psychische belasting in het werk mogelijk het gevolg van hoge betrokkenheid bij het werk of van de (ervaren) druk om te blijven werken.

\section{Zelfgerapporteerde oorzaken van verzuim}

Verzuim als gevolg van een arbeidsongeval wordt meestal onderzocht middels enquêtes. Dit kunnen kleinschalige enquêtes zijn (bijvoorbeeld binnen een bedrijf), alsook grootschalige representatieve enquêtes (meestal op landelijk niveau). In deze enquêtes wordt vaak rechtstreeks gevraagd naar het verband tussen een arbeidsongeval dat de persoon heeft meegemaakt en het verzuim dat daaruit voortvloeide. Het is echter bekend dat dergelijke attributieve vragen, zoals naar het verzuim als gevolg van een arbeidsongeval, gevoelig zijn voor vertekening (Fiske \& 
Arbeidsongevallen met lichamelijk en geestelijk letsel en de relatie met ziekteverzuim

Taylor, 1984). Uit onderzoek van De Vroome et al. (2005) komt bijvoorbeeld naar voren dat in statistische analyses de bijdrage van arbeidsongevallen aan de voorspelling van verzuim groter lijkt te zijn dan het door de respondenten zelf gerapporteerde verzuim als gevolg van een arbeidsongeval. Met andere woorden, respondenten lijken het aantal verzuimdagen ten gevolge van een arbeidsongeval te onderschatten.

Ter verduidelijking schetsen we een scenario: Johan werkt in het magazijn van een bouwmarkt en wordt tijdens zijn werk aangereden door een heftruck. Hierdoor breekt hij een been. $\mathrm{Na}$ zes weken kan hij het werk hervatten. Als gevolg van het ongeval is hij angstig geworden en schrikt van iedere heftruck die bij hem in de buurt komt. Na enkele weken moeizaam aan het werk, valt hij opnieuw uit, nu vanwege zijn angstklachten. $\mathrm{Na}$ enkele begeleidingsgesprekken met de bedrijfsarts hervat Johan zijn werk na vier weken opnieuw, tijdelijk in de winkel in plaats van in het magazijn. Wanneer we Johan vragen of hij een arbeidsongeval heeft gehad, zal hij dat bevestigen. Wanneer we vervolgens vragen hoe lang hij als gevolg van het arbeidsongeval niet heeft gewerkt, is de kans groot dat hij alleen de eerste periode van zes weken rapporteert. De tweede uitval was immers niet rechtstreeks het gevolg van het arbeidsongeval. Niettemin was het arbeidsongeval wel een belangrijke bepalende factor voor die tweede periode van verzuim. Dit scenario maakt duidelijk dat een rechtstreekse vraag naar het verzuim als gevolg van een ongeval niet altijd het volledige beeld van dit verzuim schetst. In dit onderzoek willen we daarom niet alleen het verzuim bestuderen dat een werknemer zelf toeschrijft aan een arbeidsongeval, maar ook nagaan in hoeverre werknemers met en zonder een arbeidsongeval verschillen in het totale verzuim dat zij rapporteren.

In dit artikel staan de volgende onderzoeksvragen centraal:

1 Hoeveel werkenden zijn betrokken bij arbeidsongevallen en in welke mate hebben arbeidsongevallen lichamelijk letsel en geestelijk letsel tot gevolg?
2 In hoeverre dragen arbeidsongevallen met lichamelijk en geestelijk letsel bij aan verzuim?

3 Wat is de relatie tussen rechtstreekse vragen naar verzuim als gevolg van arbeidsongevallen met het totale gerapporteerde verzuim in een jaar?

\section{Methode}

In dit onderzoek wordt gebruikgemaakt van de Nationale Enquête Arbeidsomstandigheden (NEA) (Van den Bossche \& Smulders, 2004), een onderzoek dat in 2003 is uitgevoerd onder 10.075 Nederlandse werknemers (6.499 mannen en 3.576 vrouwen). De steekproef is afkomstig uit een panel van een groot marktonderzoeksbureau. Uit dit panel zijn 23.900 personen aangeschreven met het verzoek om deel te nemen aan het onderzoek. Deze aangeschreven groep was representatief voor alle werknemers in Nederland wat betreft geslacht, leeftijd en bedrijfssector. De totale nettorespons was 42,2 procent, met een lichte ondervertegenwoordiging van vrouwen en jongeren. Dit databestand wordt ook gebruikt door Venema en De Vroome (in voorbereiding), die nader ingaan op de determinanten en gevolgen van arbeidsongevallen met geestelijk letsel.

De vragenlijst omvatte een groot aantal onderwerpen op het gebied van arbeidsomstandigheden. De vragenlijst kon op papier of via internet worden ingevuld. De vragen die in dit onderzoek aan bod komen, zijn de volgende.

\section{Demografische kenmerken}

De respondenten is gevraagd naar hun geslacht (met de antwoordcategorieën (1) vrouw en (2) man), hun geboortejaar (omgezet in leeftijd in jaren) en hun opleidingsniveau (opgedeeld in drie categorieën (1) laag, (2) midden en (3) hoog).

\section{Werkkenmerken}

De werkkenmerken die wij in dit onderzoek rapporteren, zijn gemeten met gevalideerde schalen (zie voor verdere details Van den Bossche \& Smulders, 2004) en betreffen: 
Arbeidsongevallen met lichamelijk en geestelijk letsel en de relatie met ziekteverzuim

\section{Gevaarlijk werk}

Dit is één item: 'Moet u gevaarlijk werk doen?' met de antwoordmogelijkheden: (3) ja, regelmatig, (2) ja, soms, en (1) nee.

\section{Werkdruk}

Dit is een schaal van elf items. Een voorbeelditem is: 'Moet $\mathrm{u}$ erg snel werken?' De antwoordmogelijkheden zijn: (4) altijd, (3) vaak, (2) soms, en (1) nooit. De maat voor betrouwbaarheid, Cronbach's alfa, is 0,87 .

\section{Autonomie}

Dit is een schaal van vijf items. Een voorbeelditem is: 'Kunt u zelf beslissen hoe u uw werk uitvoert?' De antwoordmogelijkheden zijn: (4) altijd, (3) vaak, (2) soms, en (1) nooit. Cronbach's alfa is 0,85 .

\section{Emotionele belasting}

Dit is een schaal van zeven items. Een voorbeelditem is: 'Is uw werk emotioneel zwaar?' De antwoordmogelijkheden zijn: (4) altijd, (3) vaak, (2) soms, en (1) nooit. Cronbach's alfa is 0,80 .

\section{Fysieke belasting/tillen}

Dit is een schaal van acht items. Een voorbeelditem is: 'Moet $\mathrm{u}$ in uw werk lasten van meer dan $5 \mathrm{~kg}$ tillen?' De antwoordmogelijkheden zijn: (4) heel vaak, (3) regelmatig, (2) soms, en (1) zelden/nooit. Cronbach's alfa is 0,94 .

\section{Trillingen}

Dit zijn twee items. Een voorbeelditem is: 'Heeft $\mathrm{u}$ in het werk trillend(e) gereedschap of apparaten in uw handen?' De antwoordmogelijkheden zijn: (4) heel vaak, (3) regelmatig, (2) soms, en (1) zelden/nooit.

\section{Houdingsbelasting}

Dit is een schaal van acht items. Een voorbeelditem is: 'Moet $u$ in uw werk buigen of draaien met uw bovenlichaam?' De antwoordmogelijkheden zijn: (4) heel vaak, (3) regelmatig, (2) soms, en (1) zelden/nooit. Cronbach's alfa is 0,85 .

\section{Repeterende bewegingen}

Dit is een schaal van drie items. Een voorbeelditem is: 'Moet $u$ in uw werk vele malen per minuut dezelfde bewegingen maken met uw arm(en)?' De antwoordmogelijkheden zijn: (4) heel vaak, (3) regelmatig, (2) soms, en (1) zelden/nooit. Cronbach's alfa is 0,94.

Voor de werkkenmerken geldt dat naarmate de schaalscore hoger is, er meer van het kenmerk aanwezig is.

\section{Arbeidsongevallen}

De respondenten is gevraagd: 'Bent $u$ in de afgelopen twaalf maanden tijdens het werk betrokken geweest bij een ongeval of voorval, waardoor u lichamelijk letsel of geestelijke schade heeft opgelopen?', met als antwoordcategorieën: (1) ja, één keer, (2) ja, meerdere keren, namelijk: ... keer, en (3) nee. Vervolgens werd gevraagd: 'Welk soort letsel heeft u hierbij opgelopen? (in geval van meerdere ongevallen: het meest recente)', met als antwoordmogelijkheden: (1) lichamelijk letsel, (2) geestelijke schade, en (3) beide.

\section{Aan ongeval toegeschreven verzuim}

Verzuim als gevolg van het ongeval is gemeten met de vraag: 'Heeft u verzuimd als gevolg van dit ongeval?', met als antwoordmogelijkheden: (1) ja, en ik ben nog steeds niet aan het werk, (2) ja, maar ik ben inmiddels weer aan het werk, en (3) nee. Hierop volgde de vraag: 'Hoe lang heeft $u$ verzuimd als gevolg van het ongeval? (tel alle dagen van begin tot eind van het verzuim: ook tussenliggende vrije dagen en weekenddagen)', met als antwoordmogelijkheden: (1) 0 dagen, (2) 1, 2 of 3 dagen, (3) 4 dagen tot 2 weken, (4) 2 weken tot 1 maand, (5) 1 maand tot 6 maanden, en (6) langer dan 6 maanden.

\section{Verzuim}

De vragen over verzuim werden ingeleid met de volgende tekst: 'Onder verzuim wordt verstaan: minder uren of dagen werken dan normaal en wel wegens ziekte, ongeval of een andere gezondheidsreden. Normaal zwangerschapsverlof wordt niet als ziekteverzuim opgevat.' Deze inleiding werd gevolgd door de vraag: 'Heeft u de afgelopen 12 maanden wel eens verzuimd?' met als antwoordmogelijkheden (1) ja, en (2) nee. Vervolgens werd gevraagd: 'Hoe vaak heeft u gedurende de afgelopen 12 maanden verzuimd?' en 'Hoeveel dagen heeft $u$, alles bij elkaar, de afgelopen 12 maanden naar schatting ver- 
Arbeidsongevallen met lichamelijk en geestelijk letsel en de relatie met ziekteverzuim

zuimd?' Bij die laatste vraag stond als toelichting: '(tel alle dagen van begin tot eind van het verzuim: ook tussenliggende vrije dagen en weekenddagen)'.

\section{Analyses}

Eerst hebben we onderzocht hoeveel respondenten betrokken zijn geweest bij een arbeidsongeval en wat de gevolgen van dit arbeidsongeval waren (onderzoeksvraag 1). Hiervoor zijn frequenties berekend.

Vervolgens is nagegaan hoe arbeidsongevallen met lichamelijk en geestelijk letsel gerelateerd zijn aan verzuim (onderzoeksvraag 2). Hiervoor hebben we eerst frequenties berekend van de verschillende typen verzuim (aan het arbeidsongeval toegeschreven verzuim en de algemene verzuimfrequentie en verzuimduur) uitgesplitst naar type letsel ten gevolge van arbeidsongeval (geestelijk letsel, lichamelijk letsel, beide en geen arbeidsongeval).

Om na te gaan hoe rechtstreekse vragen naar verzuim als gevolg van arbeidsongevallen zich verhouden tot het totale gerapporteerde verzuim van werknemers met een arbeidsongeval (onderzoeksvraag 3), zijn hiërarchische regressieanalyses uitgevoerd. Hierbij zijn respectievelijk de verzuimfrequentie en het totale aantal verzuimde dagen de afhankelijke variabelen. In stap 1 zijn als controlevariabelen het geslacht, de leeftijd en de opleiding van de respondent ingevoerd. Van deze demografische variabelen is bekend dat zij gerelateerd zijn aan zowel verzuim (Smulders, 2004) als aan het optreden van arbeidsongevallen (Venema \& Bloemhoff, 2004). Vervolgens hebben we in stap 2 de volgende werkkenmerken ingevoerd: gevaarlijk werk, werkdruk, autonomie, emotionele belasting, fysieke belasting, trillingen, houdingsbelasting en repeterende bewegingen. Daarna is in stap 3 het verzuim dat wordt toegeschreven aan het arbeidsongeval ingevoerd. Hierbij nemen we de vraag of mensen verzuimd hebben als gevolg van het ongeval bij de regressie van verzuimfrequentie. Respondenten die aangeven dat zij hebben verzuimd als gevolg van het ongeval krijgen score 1 en respondenten die geen arbeidsongeval hebben gehad of niet hebben verzuimd als gevolg van het arbeidsongeval krijgen score 0 . Bij de regressie van de totale verzuimduur voeren we zes dummyvariabelen in voor de duur van het verzuim als gevolg van een arbeidsongeval. Hierbij wordt de referentiecategorie gevormd door respondenten die geen arbeidsongeval hebben gehad of niet hebben verzuimd als gevolg van het arbeidsongeval. Ten slotte voeren we in stap 4 in de regressievergelijkingen in of een arbeidsongeval heeft geleid tot lichamelijk en tot geestelijk letsel.

Door de vraag over verzuim ten gevolge van het ongeval mee te nemen in de regressieanalyse, corrigeren we voor het door de persoon zelf aan het arbeidsongeval toegeschreven verzuim. De idee is dat wanneer respondenten hun verzuim ten gevolge van een arbeidsongeval goed inschatten, de variabelen geestelijk en lichamelijk letsel ten gevolge van een arbeidsongeval niets meer toevoegen aan de regressie van verzuim. Wanneer respondenten hun verzuim ten gevolge van een arbeidsongeval onderschatten of overschatten, zal dit tot gevolg hebben dat de variabelen geestelijk en lichamelijk letsel ten gevolge van een arbeidsongeval nog wel bijdragen aan het verklaren van verzuim.

\section{Weging}

Bij gebruikmaking van de gegevens van de NEA worden doorgaans weeggewichten toegepast om te corrigeren voor selectiviteit in de dataverzameling. Dit betekent dat sommige personen in de steekproef zwaarder meetellen dan anderen. Doel hiervan is de representativiteit van de gegevens voor de Nederlandse werknemerspopulatie te verbeteren. De weeggewichten maken de steekproef representatief naar geslacht, leeftijd, opleidingsniveau en bedrijfstak (Van den Bossche \& Smulders, 2004). In dit artikel maken we gebruik van gewogen gegevens in de beschrijvende analyses, zodat een benadering van de verdeling in de Nederlandse werknemerspopulatie wordt bereikt. In de regressieanalyses wegen we de gegevens echter niet, omdat deze analyses de onderlinge relaties tussen variabelen betreffen. Weging doet bij dergelijke analyses meer kwaad dan goed. De relaties 
Arbeidsongevallen met lichamelijk en geestelijk letsel en de relatie met ziekteverzuim

tussen variabelen in de steekproef kunnen niet door weging in overeenstemming worden gebracht met die in de populatie. Bovendien kan weging deze relaties tussen variabelen verstoren wanneer personen met extreme waarnemingen een hoog gewicht krijgen.

\section{Resultaten}

\section{Beschrijvende resultaten}

In tabel 1 is weergegeven hoeveel personen er betrokken zijn geweest bij een arbeidsongeval en wat de gevolgen van dit arbeidsongeval waren (onderzoeksvraag 1). Uit de tabel blijkt dat er (na weging) 642 personen aangaven dat ze een of meer keren bij een arbeidsongeval betrokken waren geweest. Dit is 6,5 procent van de steekproef. Van hen gaven er 145 aan dat ze bij meer arbeidsongevallen betrokken waren geweest. Op de vraag wat voor letsel de respondent bij het (meest recente) arbeidsongeval heeft opgelopen, geeft 63 procent aan dat dit lichamelijk letsel betreft, 30 procent dat het geestelijke schade betreft en 7 procent dat zij bij het ongeval zowel lichamelijk als geestelijk letsel hebben opgelopen. Minder dan de helft van de mensen $(45,7 \%)$ die een arbeidsongeval rapporteren, geeft aan te hebben verzuimd als gevolg van het ongeval. Volgens de standaarddefinitie (lichamelijk of geestelijk letsel en minimaal één dag verzuim) is er in de steekproef sprake van 285 arbeidsongevallen. Dit betreft 2,9 procent van de steekproef. Het aantal verzuimde dagen als gevolg van een arbeidsongeval is gevraagd in enkele categorieën. Zo geeft bijvoorbeeld 38,5 procent van de mensen die hebben verzuimd als gevolg van het ongeval aan dat dit verzuim vier dagen tot twee weken duurde. Wat betreft het totale verzuim in de afgelopen twaalf maanden (dus los van eventuele arbeidsongevallen) blijkt dat meer dan de helft $(54,5 \%)$ van de respondenten aangeeft dat zij wel eens verzuimd hebben in de afgelopen twaalf maanden.

\section{Bijdrage van arbeidsongevallen aan verzuim}

Hieronder gaan we na hoe letsel als gevolg van arbeidsongevallen gerelateerd is aan verzuim (onderzoeksvraag 2). Daarbij onderscheiden we verzuim dat rechtstreeks aan het arbeidsongeval wordt toegeschreven en het
Tabel 1 Arbeidsongevallen, de gevolgen van arbeidsongevallen en verzuim in de afgelopen twaalf maanden (gewogen gegevens)

\begin{tabular}{|c|c|c|}
\hline & Aantal & $\%$ \\
\hline \multicolumn{3}{|l|}{ Betrokken bij arbeidsongeval } \\
\hline Ja, één keer & 497 & 5,0 \\
\hline Ja, meerdere keren & 145 & 1,5 \\
\hline Nee & 9.300 & 93,5 \\
\hline Totaal & 9.942 & 100,0 \\
\hline Geen antwoord & 133 & \\
\hline \multicolumn{3}{|l|}{ Welk soort letsel } \\
\hline Lichamelijk letsel & 401 & 63,0 \\
\hline Geestelijke schade & 192 & 30,1 \\
\hline Beide & 44 & 6,9 \\
\hline Totaal & 636 & 100,0 \\
\hline Geen antwoord & 6 & \\
\hline \multicolumn{3}{|c|}{ Verzuim als gevolg van ongeval } \\
\hline Ja, nog niet aan het werk & 35 & 5,5 \\
\hline Ja, weer aan het werk & 256 & 40,2 \\
\hline Nee & 345 & 54,3 \\
\hline Totaal & 636 & 100,0 \\
\hline Geen antwoord & 6 & \\
\hline \multicolumn{3}{|c|}{ Duur verzuim als gevolg van ongeval } \\
\hline 0 dagen & 5 & 1,8 \\
\hline 1,2 of 3 dagen & 52 & 18,0 \\
\hline 4 dagen tot 2 weken & 112 & 38,5 \\
\hline 2 we & 45 & 15,5 \\
\hline $1 \mathrm{ma}$ & 52 & 17,8 \\
\hline Langer dan 6 maanden & 24 & 8,4 \\
\hline Totaal & 290 & 100,0 \\
\hline Geen antwoord & 1 & \\
\hline \multicolumn{3}{|c|}{ Verzuim in de afgelopen 12 maanden } \\
\hline $\mathrm{Ja}$ & 5.225 & 54,5 \\
\hline Nee & 4.367 & 45,5 \\
\hline Totaal & 9.592 & 100,0 \\
\hline Geen antwoord & 483 & \\
\hline
\end{tabular}

totale verzuim in een jaar. In tabel 2 is dit weergegeven. Wat betreft het verzuim door het ongeval blijkt uit de tabel dat mensen die aangeven dat ze lichamelijk letsel hebben opgelopen, vaker aangeven dat ze verzuimd hebben als gevolg van het arbeidsongeval $(47,7 \%)$ dan mensen die aangeven dat ze geestelijk letsel hebben opgelopen $(38,2 \%)$. Wel rapporteren mensen wat vaker langdurig verzuim als gevolg van het arbeidsongeval wanneer zij geestelijk letsel hebben opgelopen. Dit onderwerp wordt verder uitgewerkt door Venema en De Vroome (in voorbereiding). Wanneer we naar het totale verzuim in een jaar kijken, dus los van de vragen naar arbeidsongevallen, zien we dat mensen die een arbeidsongeval hebben gehad meer verzuim rapporteren $(72,8-81,1 \%)$ dan mensen 
Arbeidsongevallen met lichamelijk en geestelijk letsel en de relatie met ziekteverzuim

Tabel 2 Verzuim door ongeval en algemeen verzuim in de afgelopen twaalf maanden naar type letsel (gewogen gegevens)

\begin{tabular}{llccc}
\hline & $\begin{array}{l}\text { Geen arbeids- } \\
\text { ongeval }\end{array}$ & $\begin{array}{l}\text { Lichamelijk } \\
\text { letsel }\end{array}$ & $\begin{array}{l}\text { Geestelijk } \\
\text { letsel }\end{array}$ & $\begin{array}{l}\text { Lichamelijk en } \\
\text { geestelijk letsel }\end{array}$ \\
\hline$n$ & 9,430 & 401 & 192 & 44 \\
Verzuim door ongeval (\% ja) & - & $47,7^{\mathrm{b}}$ & $38,2^{\mathrm{a}}$ & $61,3^{\mathrm{b}}$ \\
Aantal dagen verzuim door arbeidsongeval (\%) & - & & \\
0 dagen & - & 0,7 & 1,2 & 0,0 \\
1 tot 3 dagen & - & 9,3 & 5,8 & 8,1 \\
4 dagen tot 2 weken & - & 21,9 & 7,7 & 20,9 \\
2 weken tot 1 maand & - & 6,6 & 7,4 & 8,1 \\
1 tot 6 maanden & - & 7,1 & 9,8 & 1,8 \\
meer dan 6 maanden & 1,9 & 5,8 & 12,4 \\
Verzuim afgelopen 12 maanden (\% ja) & $53,1^{\mathrm{a}}$ & $72,8^{\mathrm{b}}$ & $76,4^{\mathrm{b}}$ & $81,1^{\mathrm{b}}$ \\
Verzuimfrequentie & $1,3^{\mathrm{a}}$ & $2,2^{\mathrm{b}}$ & $2,7^{\mathrm{b}}$ & $5,7^{\mathrm{c}}$ \\
Totaal aantal dagen verzuim & $9,3^{\mathrm{a}}$ & $18,4^{\mathrm{b}}$ & $37,8^{\mathrm{c}}$ & $57,0^{\mathrm{d}}$ \\
\hline
\end{tabular}

$a b c d$ Waarden met een verschillend superscript verschillen significant van elkaar, (LSD), $p<.05$.

die geen arbeidsongeval hebben gehad $(53,1 \%)$. In tabel 2 geven we ook aan hoe vaak men heeft verzuimd in het afgelopen jaar (verzuimfrequentie) en wat het totale aantal dagen is dat men heeft verzuimd. Beide maten zijn inclusief niet-verzuimers, die een frequentie en duur van nul hebben. Uit tabel 2 komt naar voren dat de totale verzuimduur (maar niet de verzuimfrequentie) hoger is bij geestelijk letsel dan bij lichamelijk letsel. Mensen die zowel lichamelijk als geestelijk letsel rapporteren na een arbeidsongeval verzuimen het vaakst en het grootste aantal dagen in datzelfde jaar.

\section{Relatie tussen aan arbeidsongeval toegeschre- ven verzuim en het totale verzuim}

Voor de beantwoording van onderzoeksvraag 3 - waarin we nagaan hoe rechtstreekse vragen naar verzuim als gevolg van arbeidsongevallen samenhangen met het totale gerapporteerde verzuim - zijn twee hiërarchische regressieanalyses van verzuimfrequentie en verzuimduur uitgevoerd. De verklaarde variantie in iedere stap in de beide regressies is weergegeven in tabel 3 en de uiteindelijke regressievergelijkingen zijn weergegeven in tabel 4. ${ }^{1}$

Tabel 3 De uitkomsten van de hiërarchische regressieanalyses van de verzuimfrequentie en totale verzuimduur in de afgelopen twaalf maanden (ongewogen gegevens)

\begin{tabular}{|c|c|c|c|c|c|}
\hline \multirow[b]{2}{*}{ Predictor } & \multicolumn{2}{|c|}{ Verzuimfrequentie } & \multicolumn{3}{|c|}{ Totale verzuimduur } \\
\hline & $R^{2} \quad \Delta R^{2}$ & $p$ & $R^{2}$ & $\Delta R^{2}$ & $p$ \\
\hline Stap 1 geslacht, leeftijd, opleiding & 0,002 & 0,000 & & 0,009 & 0,000 \\
\hline Stap 2 werkkenmerken & 0,007 & 0,000 & & 0,023 & 0,000 \\
\hline Stap 3 verzuim door arbeidsongeval & 0,003 & 0,000 & & 0,062 & 0,000 \\
\hline Stap 4 letsel door arbeidsongeval & 0,002 & 0,000 & & 0,002 & 0,000 \\
\hline Totale regressievergelijking & 0,015 & & 0,0 & & \\
\hline
\end{tabular}


Arbeidsongevallen met lichamelijk en geestelijk letsel en de relatie met ziekteverzuim

Tabel 4 De uiteindelijke regressievergelijking met de bijdrage van persoonskenmerken, werkkenmerken, gerapporteerd verzuim als gevolg van een arbeidsongeval en geestelijk en lichamelijk letsel ten gevolge van een arbeidsongeval aan de regressie van de verzuimfrequentie en totale verzuimduur in de afgelopen twaalf maanden (ongewogen gegevens)

\begin{tabular}{|c|c|c|c|c|c|c|}
\hline \multirow[b]{2}{*}{ Predictor } & \multicolumn{3}{|c|}{ Verzuimfrequentie } & \multicolumn{3}{|c|}{ Totale verzuimduur } \\
\hline & B & Bèta & $\mathrm{p}$ & B & Bèta & $\mathrm{p}$ \\
\hline (Constant) & 0,613 & & 0,343 & $-6,845$ & & 0,096 \\
\hline $\begin{array}{l}\text { Geslacht } \\
\text { Leeftijd } \\
\text { Opleiding } \\
\text { Gevaarlijk werk } \\
\text { Werkdruk } \\
\text { Autonomie } \\
\text { Emotionele belasting } \\
\text { Fysieke belasting } \\
\text { Trillingen } \\
\text { Houdingsbelasting } \\
\text { Repeterende bewegingen }\end{array}$ & $\begin{array}{r}-0,251 \\
-0,011 \\
-0,026 \\
-0,155 \\
0,309 \\
-0,123 \\
0,213 \\
-0,246 \\
-0,090 \\
0,373 \\
0,106\end{array}$ & $\begin{array}{r}-0,025 \\
-0,025 \\
-0,004 \\
-0,018 \\
0,030 \\
-0,016 \\
0,021 \\
-0,038 \\
-0,010 \\
0,055 \\
0,024\end{array}$ & $\begin{array}{l}0,025 \\
0,023 \\
0,734 \\
0,173 \\
0,011 \\
0,138 \\
0,082 \\
0,012 \\
0,457 \\
0,000 \\
0,047\end{array}$ & $\begin{array}{r}-3,305 \\
0,187 \\
-1,516 \\
-0,395 \\
3,631 \\
-1,594 \\
3,533 \\
-0,148 \\
-0,377 \\
3,413 \\
0,122\end{array}$ & $\begin{array}{r}-0,050 \\
0,065 \\
-0,036 \\
-0,007 \\
0,052 \\
-0,032 \\
0,053 \\
-0,004 \\
-0,006 \\
0,075 \\
0,004\end{array}$ & $\begin{array}{l}0,000 \\
0,000 \\
0,002 \\
0,585 \\
0,000 \\
0,002 \\
0,000 \\
0,811 \\
0,625 \\
0,000 \\
0,720\end{array}$ \\
\hline $\begin{array}{l}\text { Verzuim door arbeidsongeval } \\
0 \text { dagen } \\
1 \text { tot } 3 \text { dagen } \\
4 \text { dagen tot } 2 \text { weken } \\
2 \text { weken tot } 1 \text { maand } \\
1 \text { tot } 6 \text { maanden } \\
\text { Meer dan } 6 \text { maanden }\end{array}$ & 0,864 & 0,029 & 0,038 & $\begin{array}{r}1,186 \\
3,665 \\
8,419 \\
12,622 \\
59,799 \\
147,532\end{array}$ & $\begin{array}{l}0,001 \\
0,008 \\
0,025 \\
0,027 \\
0,139 \\
0,191\end{array}$ & $\begin{array}{l}0,917 \\
0,468 \\
0,027 \\
0,010 \\
0,000 \\
0,000\end{array}$ \\
\hline $\begin{array}{l}\text { Lichamelijk letsel } \\
\text { Geestelijk letsel }\end{array}$ & $\begin{array}{l}0,623 \\
1,365\end{array}$ & $\begin{array}{l}0,025 \\
0,046\end{array}$ & $\begin{array}{l}0,060 \\
0,000\end{array}$ & $\begin{array}{r}-1,561 \\
8,793\end{array}$ & $\begin{array}{r}-0,009 \\
0,045\end{array}$ & $\begin{array}{l}0,462 \\
0,000\end{array}$ \\
\hline
\end{tabular}

\section{Verzuimfrequentie}

Uit tabel 3 blijkt dat de demografische variabelen in stap 1, de werkkenmerken in stap 2, de aan het arbeidsongeval toegeschreven verzuim in stap 3 en het letsel als gevolg van het arbeidsongeval in stap 4 alle significant bijdragen aan de regressie van de verzuimfrequentie. De verklaarde variantie van de verzuimfrequentie is bescheiden: 1,5 procent van de variantie in verzuimfrequentie kan verklaard worden door de veertien ingevoerde variabelen. Blijkbaar zijn andere factoren meer bepalend voor de verzuimfrequentie. Denk hierbij aan toevallige variatie in ziektegevallen (griep, verkoudheid), gezondheidsverschillen tussen personen (chronische aandoeningen) en verschillen in arbeidssatisfactie, werkmotivatie en verzuimcultuur.

In de uiteindelijke regressievergelijking (tabel 4 ) is de verzuimfrequentie hoger bij vrouwen dan bij mannen en hoger bij jongeren dan bij ouderen. Wat betreft de werkkenmerken zien we dat de verzuimfrequentie significant hoger is bij hoge werkdruk, bij lage fysieke belasting, bij hoge houdingsbelasting en bij veel repeterende bewegingen op het werk. De negatieve bijdrage van fysieke belasting is daarbij opvallend. Dit blijkt een zogenaamd 'suppressor-effect' te zijn: fysieke belasting hangt in de totale steekproef niet samen met de verzuimfrequentie maar wel sterk met houdingsbelasting. Dat betekent dat mensen die veel in een ongemakkelijk houding werken maar verder weinig fysiek zwaar werk doen relatief vaak verzuimen. Verder zien we dat indien mensen door een arbeidsongeval verzuimen, zij tevens een hogere verzuimfrequentie rapporteren dan indien zij niet verzuimd hebben als gevolg van een ongeval. Als mensen aangeven dat zij hebben verzuimd vanwege een arbeidsongeval, is de verzuimfrequentie gemiddeld (na correctie voor persoons- en werkkenmerken) 0,864 (dus bijna één verzuimepisode) hoger. Na correctie voor alle bovenstaande variabelen, dus inclusief het aan het ongeval toegeschreven verzuim, draagt lichamelijk letsel als gevolg van het 
Arbeidsongevallen met lichamelijk en geestelijk letsel en de relatie met ziekteverzuim

ongeval niet significant bij aan een hogere verzuimfrequentie, maar geestelijk letsel wel. Bij gelijkblijvende overige variabelen, leidt geestelijk letsel als gevolg van een ongeval tot een hogere verzuimfrequentie van 1,365. Dit betekent dat mensen die geestelijk letsel ondervinden van een arbeidsongeval, gemiddeld 1,4 verzuimepisodes meer hebben dan mensen die geen arbeidsongeval hebben ondergaan. Dit correspondeert met de bevindingen van tabel 2.2 Opvallend is dat geestelijk letsel - ook nadat we corrigeren voor het aan het arbeidsongeval toegeschreven verzuim - bijdraagt aan de verzuimfrequentie. Dit suggereert dat mensen met lichamelijk letsel redelijk goed in staat zijn om een inschatting te geven van het aantal keren dat ze verzuimd hebben als gevolg van het arbeidsongeval, terwijl mensen met geestelijk letsel het aantal verzuimgevallen dat voortkomt uit het arbeidsongeval onderschatten.

\section{Totale verzuimduur}

Uit tabel 3 blijkt dat ook bij de regressie van de totale verzuimduur de demografische variabelen in stap 1, de werkkenmerken in stap 2, de aan het arbeidsongeval toegeschreven verzuim in stap 3 en het letsel als gevolg van het arbeidsongeval in stap 4 alle significant bijdragen. De verklaarde variantie van de verzuimduur is aanzienlijk groter dan bij de verzuimfrequentie: 9,5 procent van de variantie in totale verzuimduur kan verklaard worden door de negentien ingevoerde variabelen.

Tabel 4 geeft de uiteindelijke regressievergelijking van de totale verzuimduur weer. Uit de tabel blijkt dat vrouwen meer dagen verzuimen dan mannen, dat ouderen meer dagen verzuimen dan jongeren, en dat lager opgeleiden meer dagen verzuimen dan hoger opgeleiden. Wat betreft de werkkenmerken blijkt dat hoge werkdruk, lage autonomie, hoge emotionele belasting en hoge houdingsbelasting samengaan met meer dagen verzuim in de afgelopen twaalf maanden. Wanneer we kijken naar de verzuimdagen die de respondenten zelf toeschrijven aan het arbeidsongeval, blijkt dat deze zoals verwacht samenhangen met de totale verzuimduur. Iemand die naar eigen zeggen vier dagen tot twee weken verzuimd heeft als gevolg van een arbeidsongeval, verzuimt (na correctie voor persoons- en werkkenmerken) gemiddeld 8,4 dagen meer dan iemand die geen arbeidsongeval heeft gehad of (naar eigen zeggen) niet heeft verzuimd na een arbeidsongeval. Bij twee weken tot één maand toegeschreven verzuim, is dat 12,6 dagen, bij één tot zes maanden is het 59,8 dagen en bij meer dan zes maanden is het 147,5 dagen verzuim extra. Mensen lijken dus redelijk consistent in hun antwoorden op de vraag naar het verzuim als gevolg van een arbeidsongeval en de algemene vraag naar verzuim in de afgelopen twaalf maanden. Na correctie voor de bovenstaande variabelen draagt lichamelijk letsel niet meer bij tot extra verzuim. Dit geeft aan dat mensen bij lichamelijk letsel een redelijk adequate inschatting geven van het verzuim dat het gevolg is van het arbeidsongeval. Geestelijk letsel draagt echter nog wel 8,8 dagen verzuim extra bij. Wellicht onderschatten mensen hoe lang zij als gevolg van het arbeidsongeval verzuimen indien zij er geestelijk letsel aan overhouden.

\section{Discussie}

Uit dit onderzoek op basis van gegevens van de Nationale Enquête Arbeidsomstandigheden (NEA) 2003 blijkt dat 6,5 procent van de werknemers in dit onderzoek in de twaalf maanden voor het onderzoek betrokken is geweest bij een arbeidsongeval. Wanneer we uitgaan van de standaarddefinitie voor arbeidsongevallen met lichamelijk of geestelijk letsel en minimaal één dag (aan dit ongeval toegeschreven) verzuim, dan geldt dit voor 2,9 procent van de werknemers in dit onderzoek. Dit onderzoek toont echter ook aan dat vragen naar verzuim dat rechtstreeks aan een arbeidsongeval wordt toegeschreven geen volledig beeld lijken te geven van dit verzuim. Personen die bij een arbeidsongeval geestelijk letsel hebben opgelopen, verzuimen meer dan zij die bij een arbeidsongeval lichamelijk letsel hebben opgelopen. Dit vinden we echter niet terug in de rechtstreekse vragen naar het verzuim als gevolg van het arbeidsongeval. Mensen met geestelijk letsel als gevolg van een arbeidsongeval lijken hun verzuim ten gevolge van het arbeidsongeval lager in te schatten dan gerechtvaardigd is. Dit geldt zowel voor de verzuimfrequentie als voor de verzuimduur. Mensen met lichamelijk letsel 
Arbeidsongevallen met lichamelijk en geestelijk letsel en de relatie met ziekteverzuim

schatten hun verzuim als gevolg van het ongeval wel goed in. De Vroome et al. (2005) vergeleken wat de persoon zelf als belangrijkste werkgerelateerde reden van hun laatste verzuimgeval aangeven met statistische verbanden tussen arborisico's en verzuim. Daaruit kwam ook naar voren dat het werkelijke effect van arbeidsongevallen op verzuim groter lijkt te zijn dan de betrokkenen zich realiseren. Uit ons onderzoek blijkt dat dit vooral opgaat voor geestelijk letsel.

Een mogelijke verklaring voor deze bevinding is dat mensen verzuim als gevolg van geestelijk letsel na een arbeidsongeval minder acceptabel vinden dan bij lichamelijk letsel na een arbeidsongeval. Hierdoor zullen werkenden met geestelijk letsel hun verzuim eerder aan andere oorzaken toeschrijven of (bewust of onbewust) lager inschatten. Een andere verklaring is dat geestelijk letsel wellicht pas in een later stadium aan het licht treedt (zie het voorbeeld van Johan in de inleiding) en dat het daardoor niet meer wordt gezien als een direct gevolg van het arbeidsongeval. Ook is het mogelijk dat het arbeidsongeval weliswaar de aanleiding is voor psychische problemen, maar dat het arbeidsongeval niet wordt gezien als de enige of de belangrijkste oorzaak van dit geestelijk letsel en het verzuim dat hieruit voortvloeit.

De hierboven beschreven onderzoeksresultaten hebben enkele theoretische, praktische en methodologische consequenties. Het ministerie van Sociale Zaken en Werkgelegenheid baseert zijn beleid op het gebied van arbeidsveiligheid mede op de Monitor Arbeidsongevallen (Venema \& Bloemhoff, 2006) die inschattingen geeft van het aantal arbeidsongevallen en de gevolgen daarvan in termen van verzuim. Tot voor kort werd daarbij uitsluitend ingegaan op lichamelijk letsel. Het huidige onderzoek geeft aan dat geestelijk letsel als gevolg van arbeidsongevallen minstens zo bepalend is voor het verzuim dat optreedt. Personen met geestelijk letsel als gevolg van een arbeidsongeval zeggen weliswaar minder vaak dat zij verzuimen vanwege het ongeval, maar als zij verzuimen duurt het langer. Bovendien lijken zij hun verzuim als gevolg van het ongeval te onderschatten en ligt hun totale verzuimduur in de afgelopen twaalf maanden hoger dan bij mensen die bij een arbeidsongeval lichamelijk letsel hebben opgelopen.

Bovendien is het van belang om bij een inschatting van de gevolgen van arbeidsongevallen niet alleen het aan het ongeval toegeschreven verzuim mee te nemen, maar ook met statistische analyses de bijdrage van arbeidsongevallen aan verzuim te onderzoeken. Werknemers die rechtstreeks gevraagd wordt naar hun verzuim als gevolg van het arbeidsongeval zijn geneigd dit te onderschatten. Dat geldt met name voor personen met geestelijk letsel als gevolg van het ongeval. Toch is het ook van belang om de zelf opgegeven redenen voor verzuim te inventariseren, omdat deze attributies onmisbaar zijn bij het categoriseren van individuele verzuimgevallen. De (statistische) bijdrage van arbeidsrisico's aan het totale verzuim in een jaar is immers alleen vast te stellen op groepsniveau en niet voor individuele personen.

Voor beleidsmakers, arbeidsorganisaties en hulpverleners is het van belang om te beseffen dat een aanzienlijk deel van arbeidsongevallen ook geestelijk letsel tot gevolg heeft en dat dergelijk geestelijk letsel sterk gerelateerd is aan het verzuim van die persoon. Het is dan ook van belang om na een arbeidsongeval niet alleen de noodzakelijke lichamelijke medische zorg te verlenen, maar ook aandacht te besteden aan de psychische gevolgen van het ongeval bij de betrokken medewerkers en hun collega's. Hoewel we op basis van het huidige onderzoek geen uitspraken kunnen doen over de effecten van dergelijke aandacht, is het waarschijnlijk dat adequate sociale steun en (zo nodig) professionele psychische hulp na een arbeidsongeval de geestelijke schade kan beperken (Cohen \& Wills, 1985). Het beperken van dergelijke geestelijke schade is niet alleen van belang in het kader van goed werkgeverschap, maar kan ook het aan het ongeval gerelateerde verzuim verminderen en is dus ook in bedrijfsmatige zin van belang.

Een sterk punt van dit onderzoek is dat gebruik is gemaakt van een groot databestand (10.075 Nederlandse werknemers), dat representatief is voor alle werknemers in Nederland wat betreft geslacht, leeftijd en bedrijfssector en waarin 
Arbeidsongevallen met lichamelijk en geestelijk letsel en de relatie met ziekteverzuim

veel relevante variabelen zijn opgenomen, waaronder demografische kenmerken, werkkenmerken, arbeidsongevallen en ziekteverzuim. Een ander sterk punt van dit onderzoek is dat niet alleen gekeken wordt naar lichamelijk letsel als gevolg van een arbeidsongeval, maar ook naar geestelijk letsel.

Er zijn echter ook enkele kanttekeningen bij dit onderzoek te plaatsen. Ten eerste zijn alle gegevens in dit onderzoek gebaseerd op zelfrapportage, dus ook de verzuimgegevens. Eerder onderzoek heeft uitgewezen dat zelfrapportage over ziekteverzuim en oorzaken van ziekteverzuim kan leiden tot onderrapportage. De Wit, Moens en Dhondt (1998) hebben zelfgerapporteerd ziekteverzuim vergeleken met verzuimgegevens van de personeelsdienst en bedrijfsarts en vonden dat er bij zelfgerapporteerd ziekteverzuim sprake is van een onderrapportage van ongeveer 12 procent (variërend van 11 tot 24 procent, afhankelijk van de bevraagde onderzoekspopulatie). Het zou dan ook interessant zijn om dit onderzoek te herhalen, maar dan met geregistreerde verzuimgegevens.

Ten tweede is er in dit onderzoek alleen gevraagd naar de gevolgen van het laatste arbeidsongeval. Een aanzienlijk deel van de werknemers die een arbeidsongeval rapporteren, geeft aan dat er meer arbeidsongevallen hebben plaatsgevonden. Dit betekent dat voor hen ook meer aan arbeidsongevallen gerelateerd verzuim kan hebben opgetreden. Uit aanvullende analyses blijkt dat mensen die meer arbeidsongevallen rapporteren inderdaad meer verzuimen dan mensen die één arbeidsongeval rapporteren. Wanneer we in de regressie van verzuim controleren voor het optreden van meer arbeidsongevallen, wijken de resultaten echter niet af van de hier gepresenteerde bevindingen. De hoofdconclusies van dit onderzoek blijven daarmee overeind: werknemers die geestelijk letsel rapporteren als gevolg van een arbeidsongeval, verzuimen vaker en langer dan werknemers die lichamelijk letsel rapporteren. Bovendien lijken werknemers met geestelijk letsel als gevolg van een arbeidsongeval dit verzuim te onderschatten.

Ten derde blijkt dat de verklaarde variantie van met name de verzuimfrequentie gering is.
Dit is gebruikelijk in onderzoeken naar verzuim. Ziekteverzuim is slechts in beperkte mate het gevolg van stabiele demografische variabelen en werkkenmerken. De meeste kortdurende verzuimgevallen hebben immers een verkoudheid of griepje als oorzaak, waardoor de meeste variatie in verzuimfrequentie toevalsvariatie is. Slechts een kleine minderheid van de verzuimgevallen is het gevolg van arbeidsongevallen, waardoor die ook slechts een klein deel van de variatie kunnen verklaren. Niettemin gaat het wel om een relevante bijdrage aan het verzuim. Het letsel en het aan het arbeidsongeval toegeschreven verzuim verklaren gezamenlijk 6,4 procent van de totale verzuimduur. Dit staat voor aanzienlijke kosten voor het Nederlandse bedrijfsleven en de maatschappij.

In de Nationale Enquête Arbeidsomstandigheden (NEA) is gevraagd naar betrokkenheid bij arbeidsongevallen en het ziekteverzuim in de afgelopen twaalf maanden. Dit is een relatief lange periode. Een voordeel van zo'n langere periode is dat dit relatief betrouwbare schattingen oplevert, omdat je minder te maken hebt met toevalsvariatie en seizoensinvloeden. Een nadeel is echter dat over een langere periode de kans groter is op onderrapportage als gevolg van herinneringsverlies (Johns, 1994).

Persoonlijkheidskenmerken van respondenten worden niet gemeten in de NEA. Het is denkbaar dat bepaalde persoonlijkheidskenmerken, zoals neuroticisme en introversie, mensen kwetsbaarder maken voor geestelijk letsel. Bovendien kunnen deze persoonlijkheidskenmerken bijdragen aan verzuim dat al dan niet gerelateerd is aan een arbeidsongeval. Dit betekent dat (een deel van) de gevonden relatie tussen gerapporteerd geestelijk letsel en verzuim in de afgelopen twaalf maanden mogelijk verklaard kan worden door persoonlijkheidskenmerken, die zowel het optreden van geestelijk letsel als het optreden van verzuim sturen. Toekomstig onderzoek zou dan ook dergelijke persoonlijkheidskenmerken moeten meenemen om deze alternatieve verklaring voor onze bevindingen te kunnen toetsen.

De aard van het lichamelijk en geestelijk letsel als gevolg van een arbeidsongeval is niet te 
Arbeidsongevallen met lichamelijk en geestelijk letsel en de relatie met ziekteverzuim

achterhalen in de NEA. In de Enquête Beroepsbevolking (EBB) wordt wel doorgevraagd naar het soort lichamelijk letsel en worden onder meer botbreuk, kneuzing, open wond of snijwond en verrekking of verstuiking onderscheiden. Het zou interessant zijn om de aard van het lichamelijk en geestelijk letsel en de relatie hiervan met verzuim nader te onderzoeken.

Uit het bovenstaande blijkt dat er nog veel mogelijkheden zijn om het inzicht in de relatie tussen arbeidsongevallen, type letsel en ziekteverzuim verder uit te bouwen. Niettemin levert het huidige onderzoek een belangrijke bijdrage aan de kennis over arbeidsongevallen met geestelijk en lichamelijk letsel en de relatie daarvan met ziekteverzuim. Uit dit onderzoek blijkt dat vooral als een arbeidsongeval leidt tot geestelijk letsel, de kans op frequent en langdurig verzuim verhoogd is. De betrokken werknemer lijkt zich in veel gevallen niet te realiseren dat dit verzuim gerelateerd is aan het arbeidsongeval. Dit betekent dat het - niet alleen voor de medewerker, maar ook voor het bedrijf - van belang is om aandacht te besteden aan de psychische gevolgen van arbeidsongevallen bij de betrokken medewerkers en na te gaan of het optreden van geestelijk letsel voorkomen of beperkt kan worden.

\section{Noten}

1 Verzuimfrequentie en verzuimduur zijn geen normaal verdeelde variabelen, maar zijn variabelen met een positieve scheefheid en een hoge kurtosis. Dit kan de resultaten van de analyses vertekenen. Een oplossing hiervoor is het analyseren van worteltransformaties of logaritmische transformaties van de afhankelijke variabelen. We hebben de regressieanalyses herhaald met dergelijke getransformeerde variabelen. Dit levert bij beide typen transformaties dezelfde conclusies op als hier gepresenteerd voor de oorspronkelijke variabelen. Hier presenteren we de regressievergelijking voor de oorspronkelijke variabelen, omdat hierbij de interpretatie van de regressiegewichten eenvoudiger is.

2 Overigens zijn beide bevindingen niet direct met elkaar te vergelijken omdat in tabel 2 niet is gecorrigeerd voor persoons- en werkkenmerken en niet voor het verzuim dat rechtstreeks wordt toegeschreven aan het betreffende arbeidsongeval.

\section{Literatuur}

Asmundson, G.J., G.R. Norton, M.D. Allerdings, P.J. Norton \& D.K. Larsen (1998). Posttraumatic stress disorder and work-related injury. Journal of Anxiety Disorders, 12: 57-69.

Barling, J., E.K. Kelloway \& R.D. Iverson (2003). Accidental outcomes: Attitudinal consequences of workplace injuries. Journal of Occupational Health Psychology, 8: 74-85.

Beckers, I., \& A. Smits (2003). Bedrijfsongevallen. Sociaal-economische maandstatistiek, 8: 17-20.

Boedeker, W. (2001). Associations between workload and diseases rarely occurring in sickness absence data. Journal of Occupational and Environmental Medicine, 43: 1081-1088.

Bossche, S.N.J. van den \& P.G.W. Smulders (2004). De Nationale Enquête Arbeidsomstandigheden 2003. Hoofddorp: TNO Arbeid.

Cohen, S., \& T.A. Wills (1985). Stress, social support, and the buffering hypothesis. Psychological Bulletin, 98: 310-357.

Fiske, S.T., \& S.E. Taylor (1984). Social cognition. Reading, MA: Addison-Wesley.

Johns, G. (1994). How often were you absent? A review of the use of self-reported absence data. Journal of Applied Psychology, 79: 574-591.

Keogh, J.P., I. Nuwayhid, J.L. Gordon \& P. Gucer (2000). The impact of occupational injury on injured worker and family: Outcomes of upper extremity cumulative trauma disorders in Maryland workers. American Journal of Industrial Medicine, 38: 498-506.

Mossink, J.C.M., E.A.P. Koningsveld \& W.S. Zwinkels (2003). Maatschappelijke kosten van arbeidsomstandigheden 2001. Den Haag: Ministerie van Sociale Zaken en Werkgelegenheid.

Ridder, M. de (1993). Zwaar arbeidsongeval en posttraumatische stress-stoornis. Veiligheidsnieuws, 101: 33-34.

Smulders, P.G.W. (2004). Ziekteverzuim: hoogte, oorzaken, aandoeningen, werkgebondenheid en maatregelen. Secundaire analyses Nationale Enquête Arbeidsomstandigheden 2003. Hoofddorp: TNO Arbeid.

Venema, A., \& A. Bloemhoff (2004). Monitor Arbeidsongevallen 2002. Hoofddorp: TNO Arbeid.

Venema, A., \& E.M.M. de Vroome (in voorbereiding). Zicht op de psychische gevolgen van arbeidsongevallen. Hoofddorp: TNO.

Venema, A. \& A. Bloemhoff (2006). Monitor Arbeidsongevallen 2004. Hoofddorp: TNO.

Vroome, E.M.M. de, P.G.W. Smulders \& C.V. van Vuuren (2005). Verzuim als gevolg van arbeidsrisico's en zelf opgegeven verzuimredenen: Deelresultaten Nationale Enquête Arbeidsomstandigheden 2003. Hoofddorp: TNO.

Wit, R. de, G. Moens \& M. Dhondt (1998). Een onderzoek naar de validiteit van zelfgerapporteerd ziekteverzuim. Arbeidsgezondheidszorg e) Ergonomie, 35: 165-168. 